NASA/TM-2003-212374

\title{
Test of Hydrogen-Oxygen PEM Fuel Cell Stack at NASA Glenn Research Center
}

David J. Bents and Vincent J. Scullin

Glenn Research Center, Cleveland, Ohio

Bei-jiann Chang, Donald W. Johnson, and Christopher P. Garcia QSS Group, Inc., Cleveland, Ohio

Ian J. Jakupca

Analex Corporation, Brook Park, Ohio 
Since its founding, NASA has been dedicated to the advancement of aeronautics and space science. The NASA Scientific and Technical Information (STI) Program Office plays a key part in helping NASA maintain this important role.

The NASA STI Program Office is operated by Langley Research Center, the Lead Center for NASA's scientific and technical information. The NASA STI Program Office provides access to the NASA STI Database, the largest collection of aeronautical and space science STI in the world. The Program Office is also NASA's institutional mechanism for disseminating the results of its research and development activities. These results are published by NASA in the NASA STI Report Series, which includes the following report types:

- $\quad$ TECHNICAL PUBLICATION. Reports of completed research or a major significant phase of research that present the results of NASA programs and include extensive data or theoretical analysis. Includes compilations of significant scientific and technical data and information deemed to be of continuing reference value. NASA's counterpart of peerreviewed formal professional papers but has less stringent limitations on manuscript length and extent of graphic presentations.

- TECHNICAL MEMORANDUM. Scientific and technical findings that are preliminary or of specialized interest, e.g., quick release reports, working papers, and bibliographies that contain minimal annotation. Does not contain extensive analysis.

- CONTRACTOR REPORT. Scientific and technical findings by NASA-sponsored contractors and grantees.
- CONFERENCE PUBLICATION. Collected papers from scientific and technical conferences, symposia, seminars, or other meetings sponsored or cosponsored by NASA.

- SPECIAL PUBLICATION. Scientific, technical, or historical information from NASA programs, projects, and missions, often concerned with subjects having substantial public interest.

- TECHNICAL TRANSLATION. Englishlanguage translations of foreign scientific and technical material pertinent to NASA's mission.

Specialized services that complement the STI Program Office's diverse offerings include creating custom thesauri, building customized databases, organizing and publishing research results ... even providing videos.

For more information about the NASA STI Program Office, see the following:

- Access the NASA STI Program Home Page at http://www.sti.nasa.gov

- E-mail your question via the Internet to help@sti.nasa.gov

- Fax your question to the NASA Access Help Desk at 301-621-0134

- Telephone the NASA Access Help Desk at 301-621-0390

- Write to:

NASA Access Help Desk

NASA Center for AeroSpace Information 7121 Standard Drive

Hanover, MD 21076 
NASA/TM-2003-212374

AIAA-2003-6123

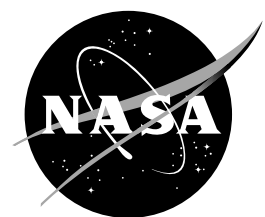

\section{Test of Hydrogen-Oxygen PEM Fuel Cell Stack at NASA Glenn Research Center}

David J. Bents and Vincent J. Scullin

Glenn Research Center, Cleveland, Ohio

Bei-jiann Chang, Donald W. Johnson, and Christopher P. Garcia QSS Group, Inc., Cleveland, Ohio

Ian J. Jakupca

Analex Corporation, Brook Park, Ohio

Prepared for the

First International Energy Conversion Engineering Conference cosponsored by the American Institute of Aeronautics and Astronautics (AIAA), the American Society of Mechanical Engineers (ASME), and the Institute of Electrical and Electronics Engineers (IEEE)

Portsmouth, Virginia, August 17-21, 2003

National Aeronautics and

Space Administration

Glenn Research Center 
This report is a preprint of a paper intended for presentation at a conference. Because of changes that may be made before formal publication, this preprint is made available with the understanding that it will not be cited or reproduced without the permission of the author.

Available from

NASA Center for Aerospace Information 7121 Standard Drive

Hanover, MD 21076
National Technical Information Service 5285 Port Royal Road Springfield, VA 22100

Available electronically at http:/ /gltrs.grc.nasa.gov 


\title{
TEST OF HYDROGEN-OXYGEN PEM FUEL CELL STACK AT NASA GLENN RESEARCH CENTER
}

\author{
David J. Bents ${ }^{*}$ and Vincent J. Scullin ${ }^{\dagger}$ \\ National Aeronautics and Space Administration \\ Glenn Research Center \\ Cleveland, Ohio 44135 \\ Bei-jiann Chang, Donald W. Johnson, and Christopher P. Garcia \\ QSS Group, Inc. \\ Cleveland, Ohio 44135 \\ Ian J. Jakupca \\ Analex Corporation \\ Brook Park, Ohio 44142
}

\begin{abstract}
This paper describes performance characterization tests of a 64-cell hydrogen oxygen PEM fuel cell stack at NASA Glenn Research Center in February 2003. The tests were part of NASA's ongoing effort to develop a regenerative fuel cell for aerospace energy storage applications. Purpose of the tests was to verify capability of this stack to operate within a regenerative fuel cell, and to compare performance with earlier test results recorded by the stack developer. Test results obtained include polarization performance of the stack at 50 and 100 psig system pressure, and a steady state endurance run at $100 \mathrm{psig}$. A maximum power output of $4.8 \mathrm{kWe}$ was observed during polarization runs, and the stack sustained a steady power output of $4.0 \mathrm{kWe}$ during the endurance run. The performance data obtained from these tests compare reasonably close to the stack developer's results although some additional spread between best to worst performing cell voltages was observed. Throughout the tests the stack demonstrated the consistent performance and repeatable behavior required for regenerative fuel cell operation.
\end{abstract}

\section{INTRODUCTION}

The NASA GRC is supporting the development of an aerospace hydrogen-oxygen regenerative fuel cell (RFC) under the Environmental Research Aircraft and Sensor Technology (ERAST) project of the Flight Research Base Program. The ERAST charter includes the development and demonstration of new technologies for unmanned aircraft that are suitable for earth science, including RFC equipped solar electric aircraft with potentially unlimited endurance. Although ERAST is an Aeronautics project, the RFC is a solar energy storage device applicable to a wide variety of space and planetary surface missions as well as high altitude solar electric flight; hence, widespread interest throughout NASA to bring this technology to a flight demonstration. Potentially the highest storage capacity and lowest weight of any non-nuclear device, an RFC flown aboard a solar electric aircraft continuously through several successive day-night cycles will provide the most convincing demonstration this technology's widespread potential has been realized. Leading up to the flight demonstration are several laboratory and full scale demonstrations of key components, such as the fuel cell stack described in this paper.

\section{BACKGROUND}

The fuel cell stack, which converts stored hydrogen and oxygen back to electrical power in the RFC, is considered the most important key component. GRC has a test stand for hydrogen-oxygen fuel cells in the Rocket Combustion Laboratory (RCL) built up for performance testing which has been in operation since January 2000. This test stand, located in test cell 24 of the RCL, can accommodate fuel cell stacks up to 72 cells producing stack currents up to 200 A. A detailed description of the test stand and operating limitations is presented in Table 1, with a schematic diagram of the thermal/fluid systems presented in Figure 1. The test cell is serviced by bottled hydrogen and oxygen supplies placed in revetments outside the building and is well ventilated, conforming to applicable safety

"Thermo-Mechanical Systems Branch

${ }^{\dagger}$ Scientific Applications Development Branch 
TABLE 1.-HYDROGEN-OXYGEN FUEL CELL TEST STAND

\begin{tabular}{|c|c|c|c|}
\hline \multicolumn{4}{|c|}{ Applied Conditions and Input Parameters } \\
\hline Applied condition parameter & Controlled by & Range & $\begin{array}{l}\text { Unit of } \\
\text { measure }\end{array}$ \\
\hline \multicolumn{4}{|l|}{ Operating pressure: } \\
\hline $\mathrm{O} 2$ pressure & oxygen exit line back pressure regulator & 0 to 400 & psig \\
\hline $\mathrm{H} 2$ pressure & hydrogen exit line back pressure regulator & 0 to 400 & psig \\
\hline $\mathrm{H} 2$ to $\mathrm{O} 2$ stream $\Delta \mathrm{P}$ & coordination of hydrogen and oxygen exit pressures & \pm 25 & psid \\
\hline \multicolumn{4}{|l|}{ Flow rates: } \\
\hline $\mathrm{O} 2$ flow rate & oxygen inlet mass flow controller & 0 to 50 & SLPM \\
\hline H2 flow rate & hydrogen inlet mass flow controller & 0 to 80 & SLPM \\
\hline Operating temperature: & (see below) & 120 to 150 & ${ }^{\circ} \mathrm{F}$ \\
\hline Coolant exit temperature & PID setpoint control diverter valve WB742 & 70 to 140 & ${ }^{\circ} \mathrm{F}$ \\
\hline $\mathrm{O} 2$ inlet temperature & oxygen humidifier tank and line heaters & 70 to 140 & ${ }^{\circ} \mathrm{F}$ \\
\hline $\mathrm{H} 2$ inlet temperature & hydrogen humidifier tank and line heaters & 70 to 140 & ${ }^{\circ} \mathrm{F}$ \\
\hline \multicolumn{4}{|l|}{ Inlet humidification: } \\
\hline $\mathrm{O} 2$ inlet dewpoint & oxygen humidifier tank and line heaters & 70 to 140 & ${ }^{\circ} \mathrm{F}$ \\
\hline $\mathrm{H} 2$ inlet dewpoint & hydrogen humidifier tank and line heaters & 70 to 140 & ${ }^{\circ} \mathrm{F}$ \\
\hline Stack current (applied load) & electronic load unit & 0 to 100 & amperes \\
\hline \multicolumn{4}{|c|}{ Output Measurements } \\
\hline \multicolumn{4}{|l|}{ Fuel cell stack performance parameters } \\
\hline Stack voltage & & 35 to 70 & volts \\
\hline \multicolumn{4}{|l|}{ Individual cell voltage: } \\
\hline Maximum & & 1.1 & volts \\
\hline Average & & 0.75 to 0.9 & volts \\
\hline Minimum & & 0.5 & volts \\
\hline Stack power output & voltage $\mathrm{X}$ current & 1400 to 5250 & watts \\
\hline
\end{tabular}



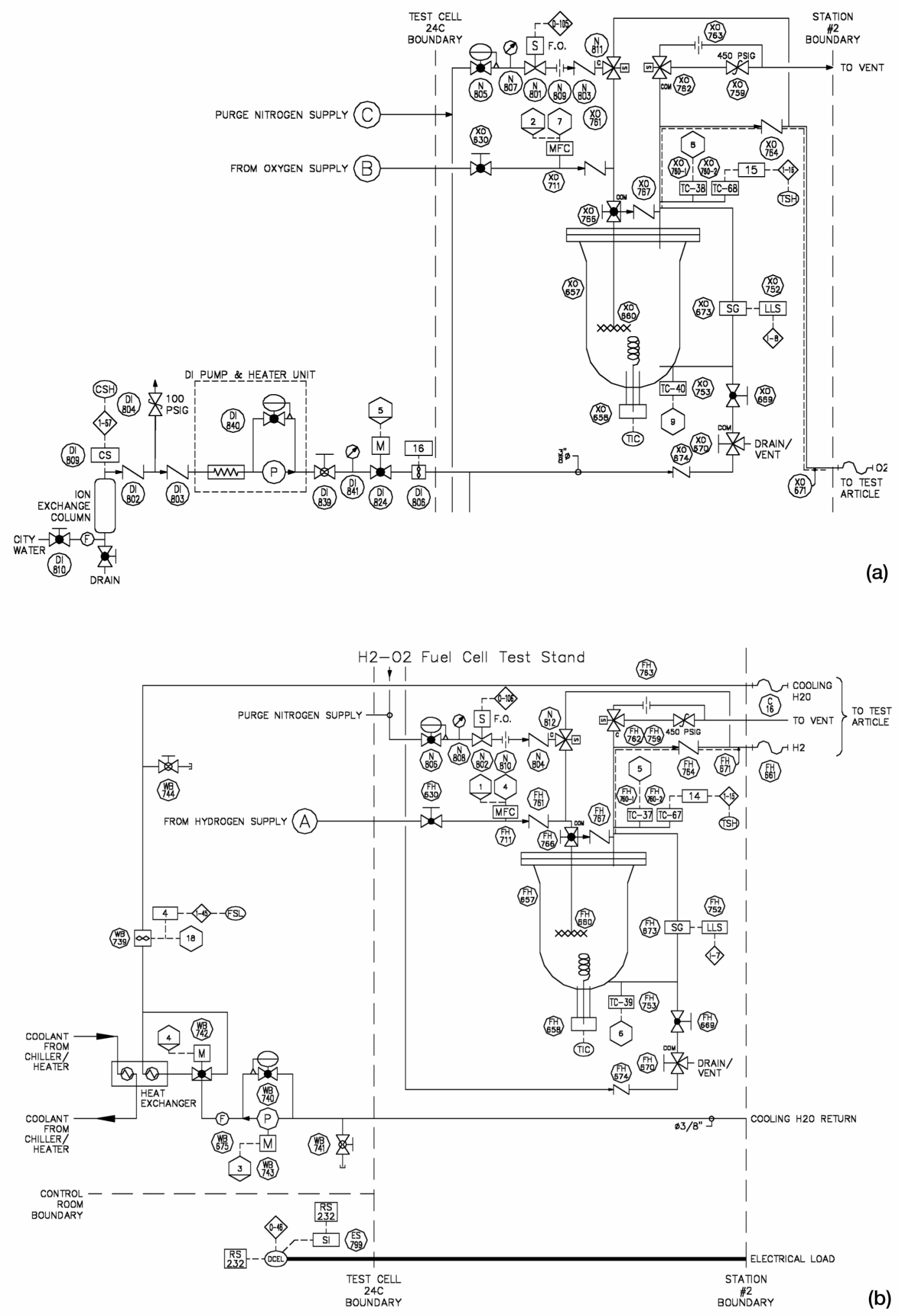

Figure 1. $-\mathrm{H}_{2}-\mathrm{O}_{2}$ fuel cell test stand at NASA GRC. (a) $\mathrm{O}_{2}$ inlet conditioning and flow controls. (b) $\mathrm{H}_{2}$ and coolant inlet conditioning, electrical load, and flow controls. 


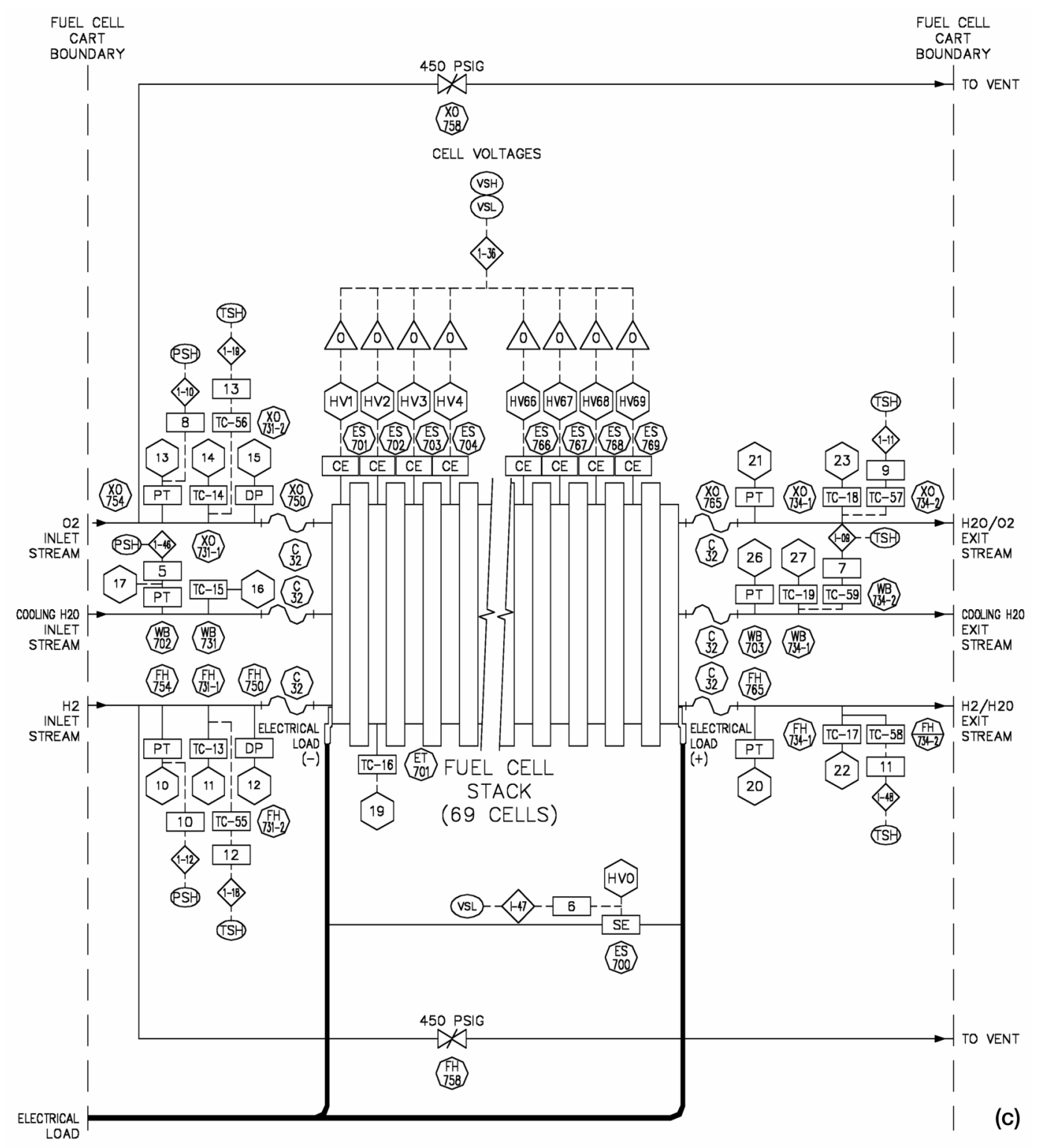

Figure 1.-Continued. (c) Test article and instrumentation. 


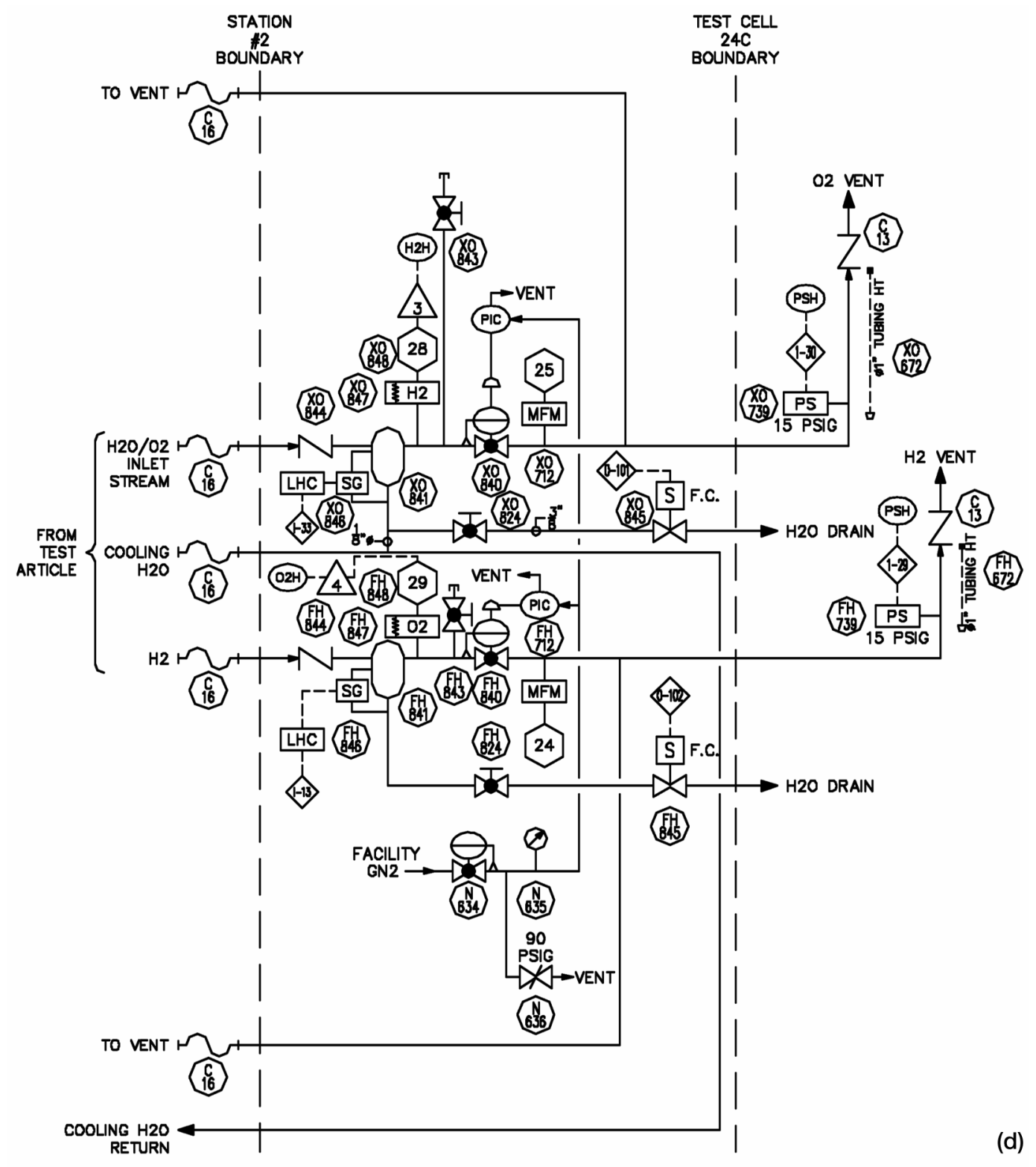

Figure 1.-Concluded. (d) Exit stream phase-sep., pressure control and venting.

standards for systems utilizing hydrogen and pure oxygen compressed gasses (Refs. 1 to 5).

Figure 2 shows a recent photograph of the cell 24 interior. The fuel cell stack test stand is in the foreground with the test article mounted.

Main purpose of this test stand is to make detailed open loop characterizations of multi-cell stacks controlling the input parameters and applied loads (see Table 1, "Applied Conditions") while measuring, observing, and recording the performance parameters listed in "Output
Measurements." The data are compared with theoretical performance predictions traceable to the stacks' physical design, or the developer's performance predictions, or performance noted for similar stacks made by others.

Of particular interest to a fuel cell system designer are

- polarization performance at operational temperature and pressure

- operational life and performance consistency/ repeatability over time 


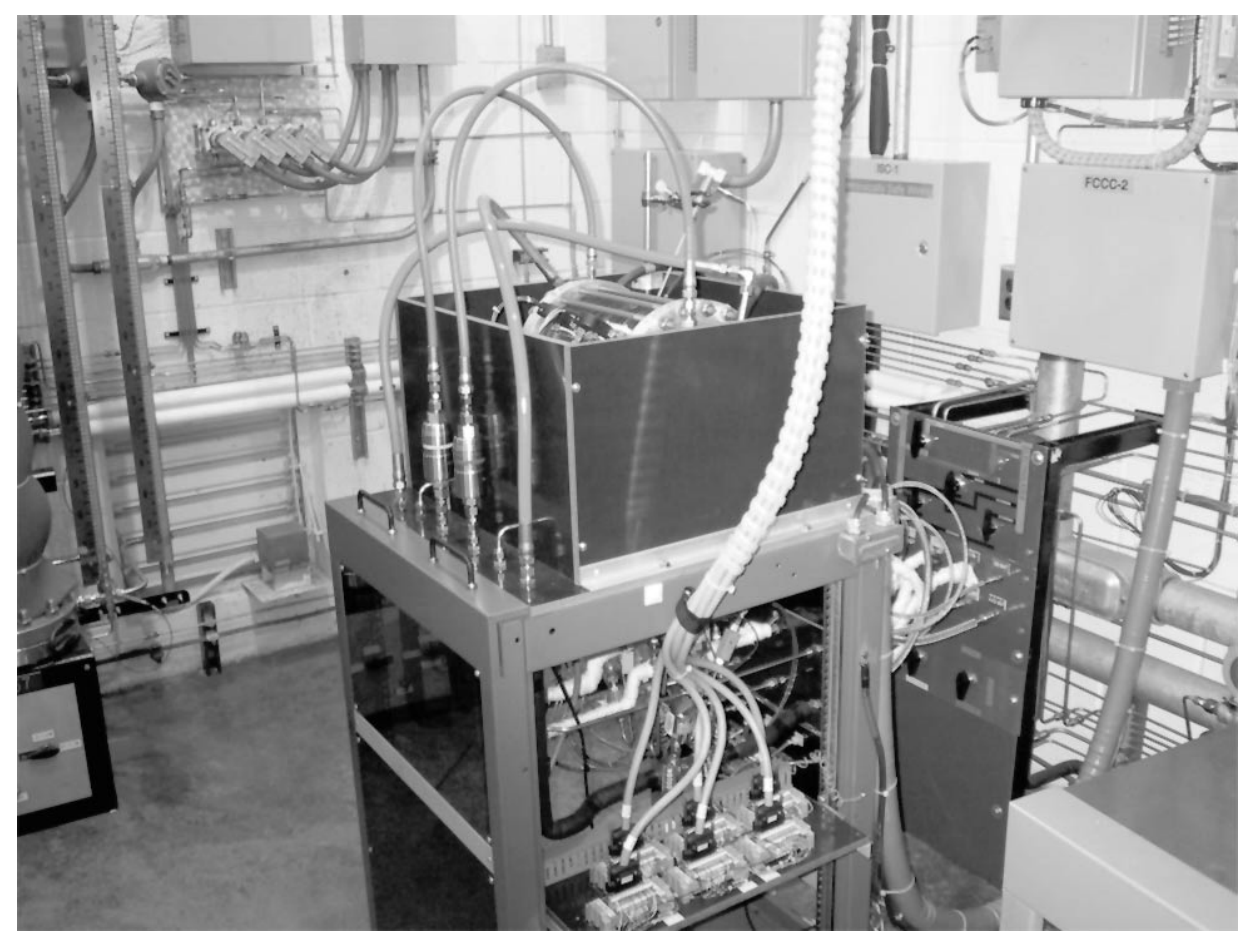

Figure 2.-Lynntech G3 fuel cell stack on RCL24 test stand at NASA GRC 26 Feb. 2003.

\section{TEST ARTICLE}

The fuel cell stack tested was a 64-cell hydrogen oxygen PEM unit designed and built by Lynntech, Inc. (College Station, Texas) designated "Generation III" in reference to its place in that company's continuing design evolution. Lynntech is the industry partner furnishing stacks for the Aerovironment "Helios" solar electric aircraft RFC demonstration; their stack design has undergone several revisions and improvements since the original concepts, realized in the form of a 4-cell developmental short stack, were tested in early 2000. These improvements were the product of careful failure analysis and rework following extensive testing at Lynntech, Aerovironment, and GRC.

From earlier designs such as the predecessor Gen II 4-cell short stack which was tested at GRC in September 2000, there emerged a more consistent performing short stack configuration in 2001 which was tested to failure in May 2001, then rebuilt and tested to failure again in June 2001, and again in October 2001 (Ref. 6). The short stacks had consistently good electrochemical performance but were subject to some MEA failures and crossover. The failure mechanism was eventually isolated and solved, and a modified Generation III short stack tested in January 2002 showed generally robust behavior and no more recurrences. Further testing in February 2002 confirmed performance and reliability of the new configuration.

Following success with the short stacks, Lynntech moved forward with construction of a full size 64-cell stack (the test article) which they operated at full power for $100 \mathrm{hr}$ before delivering it to Aerovironment in February 2002 (Ref. 7). The stack was used to support AV's Helios prototype RFC pod demonstration in March 2002 (Ref. 8). Following a successful pod demonstration, the stack was removed and shipped to GRC for further evaluation.

GRC tested the stack in December of 2002 but the tests were curtailed by test stand problems including inadequate stack cooling and oxygen flows. These problems were fixed during January and February of 2003, and the stack was returned to the stand for testing during the week of February 17, 2003. Testing began February 19 and was completed February 27, 2003.

\section{TEST NARRATIVE, RESULTS, AND DISCUSSION}

The stack was subjected to "non-operational" performance tests February 19th prior to being operated 
on the stand. The stack passed the no-op tests; all diagnostic parameters were within the developer's acceptable limits.

The stack was then connected to the test stand and energized with reactant gasses. As hydrogen and oxygen reactants were absorbed into the stack displacing purge nitrogen, the following open circuit voltage profile shown in Figure 3 began to emerge. The low cell to cell voltage variation observed also indicated a healthy stack.

Non-op tests were repeated February 25th prior to operational testing. Readings were close to those observed February 19th. With reactant flows established, the stack was then pressurized to 50 psig and electrical loads were applied. Then the pressure was raised to $70 \mathrm{psig}$, and load currents to a maximum of $100 \mathrm{~A}$ were applied to the stack. At $100 \mathrm{~A}$ some of the cells began to flood and could not sustain $100 \mathrm{~A}$ for more than 5 minutes, so oxygen flow rate was raised to the maximum (reduce utilization) in hopes of stabilizing the water balance in those cells. Keeping high inlet oxygen flow (50 SLPM) allowed the stack to sustain stable operation at $80 \mathrm{~A}$. After stable operation was demonstrated at $70 \mathrm{psig}$, pressure was reduced to 50 psig and stable operation was again demonstrated at 80 A load current. Then, pressure was increased to 100 psig and a third stable operating point at $80 \mathrm{~A}$ was demonstrated. Figure 4 shows the cell voltage profile at a load current of $80 \mathrm{~A}$. The stack was operated at this condition for approximately 45 minutes.

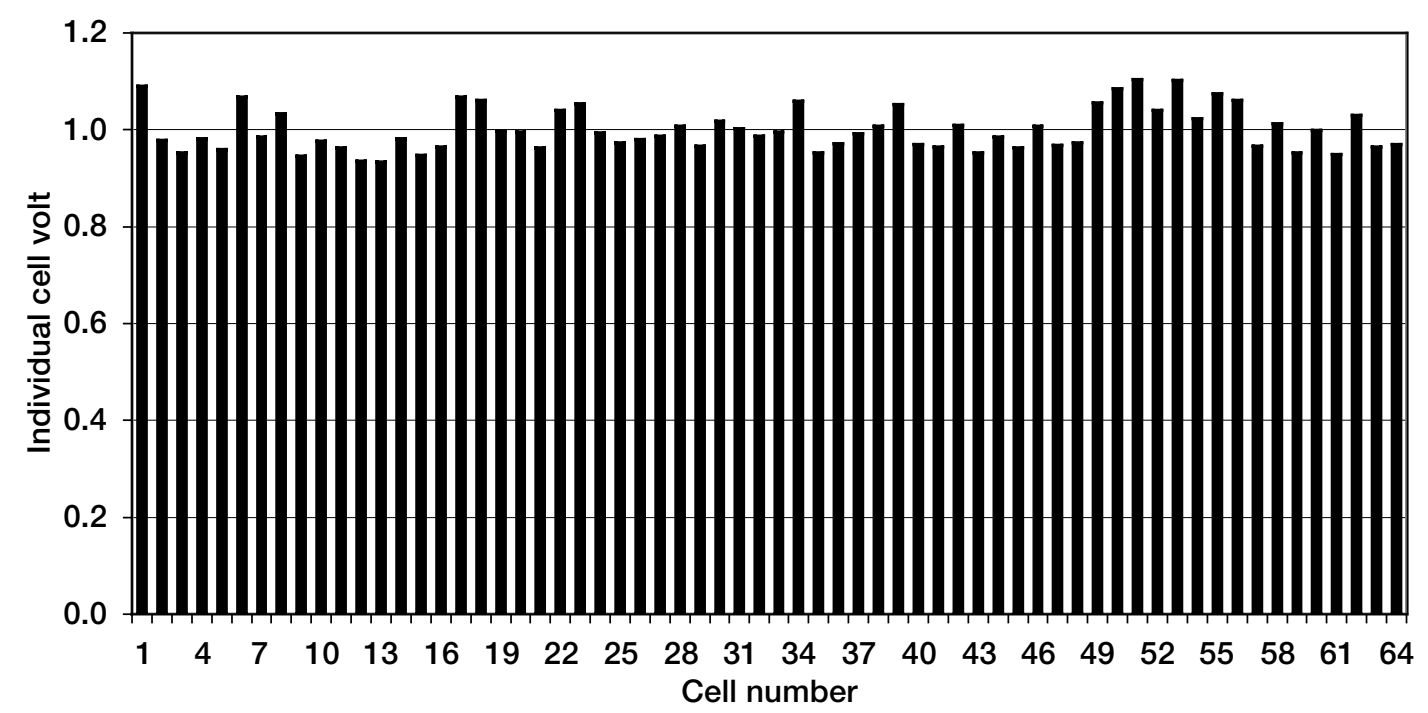

Figure 3.-Open circuit voltage profile with reactants flowing.

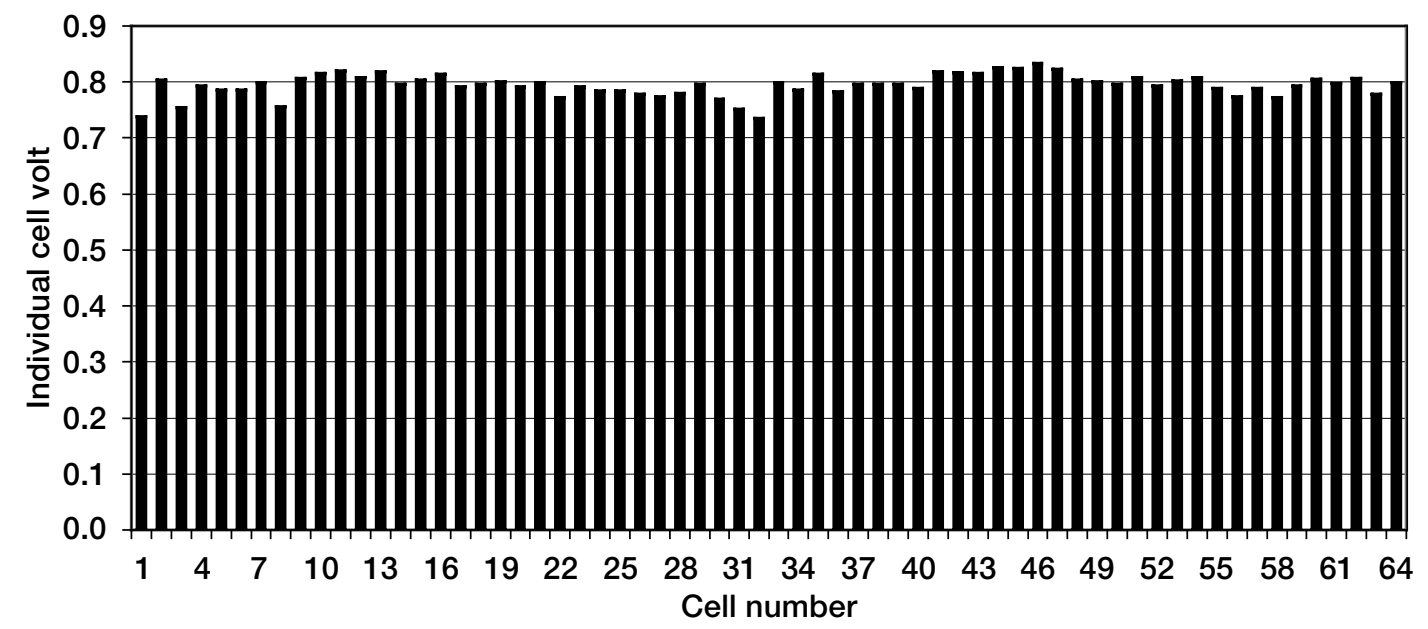

Figure 4.-Stack voltage profile at $100 \mathrm{psig}, 80 \mathrm{~A}$ load. 

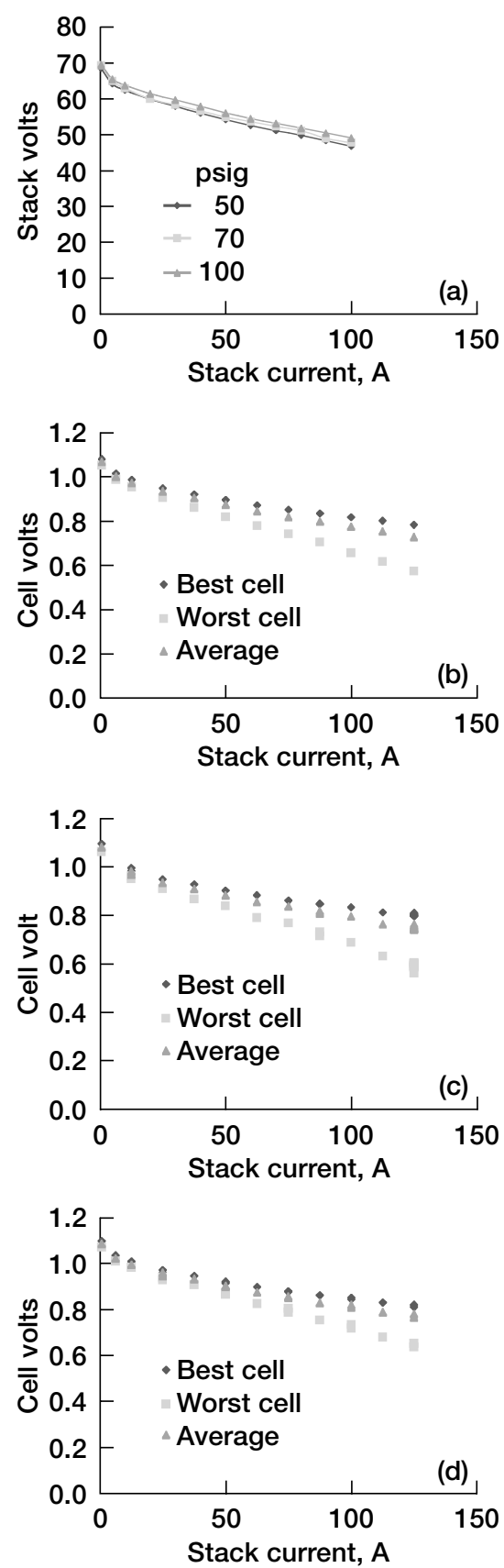

Figure 5.-(a) Lynntech G3 stack at $57^{\circ} \mathrm{C}$. Stack polarization performance at nominal conditions. (b) Polarization at 50 psig, nominal conditions-best, worst, and average cell performance. (c) Polarization at 70 psig, nominal conditions-best, worst and average cell performance. (d) Polarization at 100 psig, nominal conditions-best, worst and average cell performance.

The stack was then subjected to polarization performance tests at $50 \mathrm{psig}$ and $100 \mathrm{psig}$. During these tests, electrical load was increased from idle in steps of $10 \mathrm{~A}$, to a maximum current of $100 \mathrm{~A}$, then stepwise

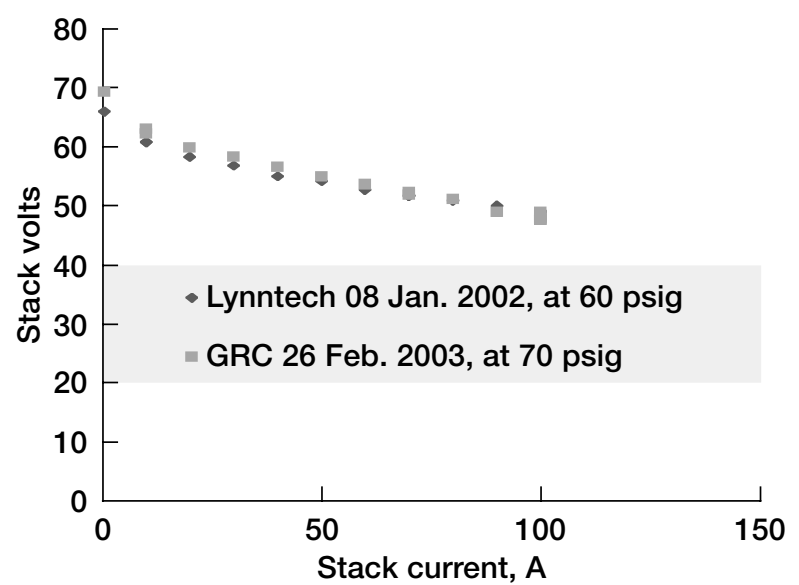

Figure 6.-Stack polarization comparison to earlier tests.

downwards in 10 A steps from $100 \mathrm{~A}$ back to idle. The test was also applied in reverse order, beginning with the maximum current and stepping down to idle and back in $10 \mathrm{~A}$ steps. The resulting cell and stack voltage versus current profiles were tabulated and are presented in Figures 5(a) to 5(d).

The polarization curves shown in these figures are the primary representations by which the electrochemical performances of similar stacks may be compared. For example it is useful to compare the 50 psig polarization performance recorded at GRC (Fig. 5(a)) with the $60 \mathrm{psig}$ performance reported by the developer after $100 \mathrm{hr}$ of acceptance testing 18 months ago (data from Fig. 4 of Ref. 7), which is plotted alongside the more recent data in Figure 6.

For a measurement of stack degradation we may look at the variation of individual cell voltages that were recorded during an individual polarization test, and compare with earlier polarization test data. For example, Figure 5(c) shows the best, worst, and average cell voltages recorded at GRC for the stack at 70 psig. Figure 7 (reproduced from Fig. 5 of Ref. 7) shows the individual cell voltages that were recorded by the developer under similar conditions approximately one year earlier. The plot shows all the individual cell voltages but its envelope is bounded by the best and worst performing cells. From comparison of Figure 5(c) to Figure 7 it appears overall stack degradation has remained less than ten percent, but best-to-worst cell voltage spread has approximately doubled.

Following polarization testing the stack was subjected to an endurance run at $100 \mathrm{psig}$, carried out during the afternoon of February 26. Run duration was limited by the available hydrogen supply ( 2 full "K" bottles) which 


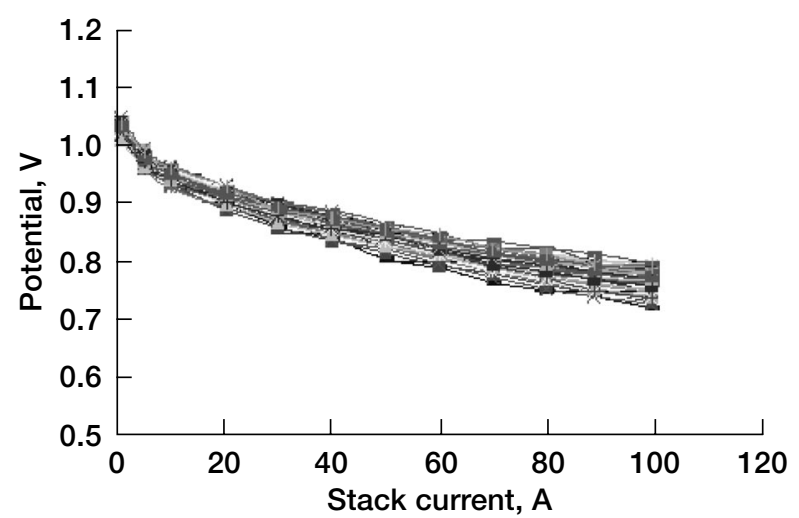

Figure 7.-Stack developer's "Individual cell IE curves, 60 psig, after 100 hours operation" reproduced from Ref. 7.

was exhausted after $4.5 \mathrm{hr}$ of running. The run conditions were maintained at $80 \mathrm{~A}$ output for approximately $4.5 \mathrm{hr}$.

On the following day, the stack was subjected to non-op tests to ascertain health status. The non-op tests indicated the stack had suffered no damage during the tests, and was fully capable of continued operation.

\section{CONCLUSIONS}

The good electrochemical performance exhibited by this stack after several cycles of inactivity, and the limited degradation that was observed, indicates the stack is capable of supporting closed loop operation in a regenerative fuel cell system. The stack was removed from test stand on March 4, 2003, capped off, and transported to the Bldg. 135 closed loop test rig for integration into the regenerative fuel cell system.

\section{REFERENCES}

1. NASA Glenn Research Center Safety Manual, NHB1700.1, National Aeronautics and Space Administration, 1997. Website http://osatext.grc.nasa.gov/gso/manual/chapter_index.shtml

2. NFPA 50a Standard for Gaseous Hydrogen at Consumer Sites, National Fire Protection Association, Atlanta, Georgia, 1999.

3. NFPA 50 Standard for Bulk Oxygen Systems at Consumer Sites, National Fire Protection Association, Chicago, Illinois, 1996.

4. NFPA 51 Standard for Design and Installation of Oxygen-Fuel Gas Systems for Welding, Cutting, and Allied Processes, National Fire Protection Association, Nashville, Tennessee, 1997.

5. NFPA 70 National Electrical Code, Hazardous Locations, Classes I, II, and III, Divisions 1 and 2, National Fire Protection Association, Anaheim, California, 2001.

6. NASA Glenn Research Center, Aero Base Project, monthly reports:
a. "ERAST September 2000 progress"
b. "ERAST May 2001 progress"
c. "ERAST June 2001 progress"
d. "ERAST October 2001 progress"
e. "ERAST January 2002 progress"
f. "ERAST February 2002 progress"

7. Lynntech, Inc., "Instruction Manual, Generation III Fuel Cell Stack," Lynntech, Inc., College Station, Texas, January 08, 2002.

8. NASA Dryden Flight Research Center Press Release 02-2, "Helios Energy Storage System Passes Major Functional Test," April 24, 2002. 
Public reporting burden for this collection of information is estimated to average 1 hour per response, including the time for reviewing instructions, searching existing data sources, gathering and maintaining the data needed, and completing and reviewing the collection of information. Send comments regarding this burden estimate or any other aspect of this collection of information, including suggestions for reducing this burden, to Washington Headquarters Services, Directorate for Information Operations and Reports, 1215 Jefferson Davis Highway, Suite 1204, Arlington, VA 22202-4302, and to the Office of Management and Budget, Paperwork Reduction Project (0704-0188), Washington, DC 20503.

\begin{tabular}{|l|l|l|}
\hline 1. AGENCY USE ONLY (Leave blank) & $\begin{array}{c}\text { 2. REPORT DATE } \\
\text { September } 2003\end{array}$ & $\begin{array}{r}\text { 3. REPORT TYPE AND DATES COVERED } \\
\text { Technical Memorandum }\end{array}$ \\
\hline
\end{tabular}

\section{TITLE AND SUBTITLE} 5. FUNDING NUMBERS

Test of Hydrogen-Oxygen PEM Fuel Cell Stack at NASA Glenn Research Center

\section{6. $\operatorname{AUTHOR(S)}$}

David J. Bents, Vincent J. Scullin, Bei-jiann Chang, Donald W. Johnson, Christopher P. Garcia, and Ian J. Jakupca

\section{PERFORMING ORGANIZATION NAME(S) AND ADDRESS(ES)}

National Aeronautics and Space Administration

John H. Glenn Research Center at Lewis Field

Cleveland, Ohio 44135-3191

WBS-22-710-10-02

\section{SPONSORING/MONITORING AGENCY NAME(S) AND ADDRESS(ES)}

National Aeronautics and Space Administration

Washington, DC 20546-0001

8. PERFORMING ORGANIZATION REPORT NUMBER

E-13950

\section{SUPPLEMENTARY NOTES}

Prepared for the First International Energy Conversion Engineering Conference cosponsored by the American Institute of Aeronautics and Astronautics (AIAA), the American Society of Mechanical Engineers (ASME), and the Institute of Electrical and Electronics Engineers (IEEE), Portsmouth, Virginia, August 17-21, 2003. David J. Bents and Vincent J. Scullin, NASA Glenn Research Center; Bei-jiann Chang, Donald W. Johnson, and Christopher P. Garcia, QSS Group, Inc., Cleveland, Ohio 44135; Ian J. Jakupca, Analex Corporation, Brook Park, Ohio 44142. Responsible person, David J. Bents, organization code 5490, 216-433-6135.

12a. DISTRIBUTION/AVAILABILITY STATEMENT 12b. DISTRIBUTION CODE

Unclassified - Unlimited

Subject Categories: 44, 07, and 20

Distribution: Nonstandard

Available electronically at http://gltrs.grc.nasa.gov

This publication is available from the NASA Center for AeroSpace Information, 301-621-0390.

13. ABSTRACT (Maximum 200 words)

This paper describes performance characterization tests of a 64 cell hydrogen oxygen PEM fuel cell stack at NASA Glenn Research Center in February 2003. The tests were part of NASA's ongoing effort to develop a regenerative fuel cell for aerospace energy storage applications. The purpose of the tests was to verify capability of this stack to operate within a regenerative fuel cell, and to compare performance with earlier test results recorded by the stack developer. Test results obtained include polarization performance of the stack at 50 and 100 psig system pressure, and a steady state endurance run at $100 \mathrm{psig}$. A maximum power output of $4.8 \mathrm{kWe}$ was observed during polarization runs, and the stack sustained a steady power output of $4.0 \mathrm{kWe}$ during the endurance run. The performance data obtained from these tests compare reasonably close to the stack developer's results although some additional spread between best to worst performing cell voltages was observed. Throughout the tests, the stack demonstrated the consistent performance and repeatable behavior required for regenerative fuel cell operation.

\section{SUBJECT TERMS}

Regenerative fuel cells; Energy storage

15. NUMBER OF PAGES

15

16. PRICE CODE

\begin{tabular}{l|c} 
17. SECURITY CLASSIFICATION \\
$\begin{array}{c}\text { OF REPORT } \\
\text { Unclassified }\end{array}$ & $\begin{array}{c}\text { 18. SECURITY CLASSIFICATION } \\
\text { OF THIS PAGE } \\
\text { Unclassified }\end{array}$
\end{tabular}

NSN 7540-01-280-5500
19. SECURITY CLASSIFICATION OF ABSTRACT

Unclassified

\section{LIMITATION OF ABSTRACT}

Standard Form 298 (Rev. 2-89)

Prescribed by ANSI Std. Z39-18 298-102 